\title{
Comparison Analysis of Developmentalism in Globalization Era: Indonesia Joko Widodo's Presidency (2014-2019) and South Korea Moon Jae-In Presidency (2017-2020)
}

\author{
Darynaufal Mulyaman ${ }^{1 *}$, Achmad Ismail ${ }^{2}$, Nadya Carollina ${ }^{3}$, Morry Zefanya ${ }^{4}$ \\ 1Universitas Kristen Indonesia, Jakarta, Indonesia, email: darynaufal.mulyaman@uki.ac.id \\ 2Universitas Jakarta, Jakarta, Indonesia, email: ismailachmad@rocketmail.com \\ 3Universitas Kristen Indonesia, Jakarta, Indonesia, email: nadyacarollina@outlook.com \\ ${ }^{4}$ Universitas Kristen Indonesia, Jakarta, Indonesia, email: morryzp@gmail.com \\ ${ }^{*}$ Corresponding Author
}

\begin{tabular}{|c|c|}
\hline Artic & Abstract \\
\hline 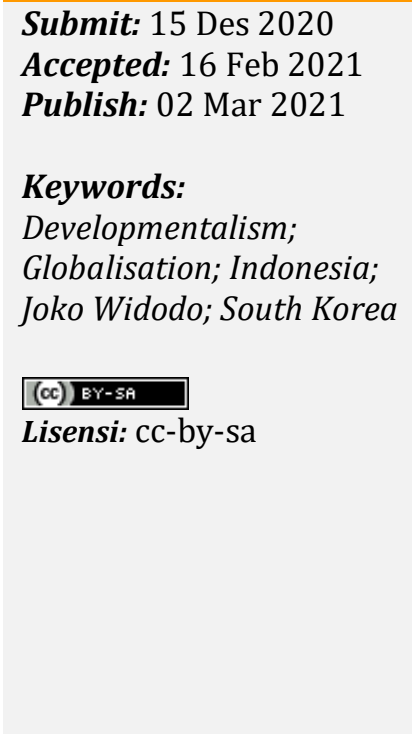 & $\begin{array}{l}\text { In the globalized age, freedom in capital and workforce movement, self } \\
\text { expression, and information openness become vital, including in Asian } \\
\text { countries like Indonesia and South Korea. Thus innovation and creativity } \\
\text { have become an important key in recent eras. New kinds of innovation and } \\
\text { creativity that are established by Asian countries sometimes are nostalgic } \\
\text { policies by the previous regime of the government. Therefore, Indonesia still } \\
\text { comes up with a kind of centralistic governance and planning with a twist } \\
\text { of free and liberal market policy, a developmental style of New Order } \\
\text { governance to some extent. Hence, why is developmentalism in Indonesia } \\
\text { still relevant? Even when there are shifts in the regimes and globalization } \\
\text { process of the world. This paper argues that the policy series that has been } \\
\text { initiated in Indonesia under President Joko Widodo is still part of } \\
\text { developmentalism because of the historical and political context in a } \\
\text { broader sense on developmentalism, therefore still relevant in Indonesia. } \\
\text { This paper also uses the South Korean case of current policy under } \\
\text { President Moon Jae-In to compare and assign Indonesian } \\
\text { developmentalism relevancy as South Korea can be seen as one of the } \\
\text { successful examples of developmentalism yet liberal country. }\end{array}$ \\
\hline
\end{tabular}

INTRODUCTION

Globalization in recent years opens all kinds of possibilities around the globe. Openness and speed are modals to keep up with all the technology and information. Innovation and creativity are the key elements to tap into a highly competitive economy in globalization. Despite globalization, some countries are regenerating their old policy into recent age because it could help them to settle with some issues. Despite all of the innovations needed to thrive in a globalized world, sometimes the best procedure may be the old procedure that had been used before. South Korean policy toward North Korea for example, President Moon Jae-In famously being cooperative with his North Korean counterpart similar to former President Kim Dae-Jung with his Sunshine Policy.

Not only Korea but also Indonesia that reminiscing old policy. In Indonesia, several actions that have been taken by Joko Widodo's administration may resemble or similar in a way to Indonesia's previous administration. One of the examples is one third of the Indonesian economy is still being led by SoE or state owned enterprises or BUMN (Badan Usaha Milik Negara). Erick Thohir, the newly elected Minister of State Owned 
Enterprises in Jokowi's recent Onward Indonesia Cabinet has implied that if one third of Indonesia's economy is led by SoE could give great impacts on Corona attacked Indonesia. In another way, we can say that the Indonesian government still has a big impact and stake on the economy of Indonesia (Indraini, 2020). Therefore, developmentalism is "the form of economic and political organization alternative to economic liberalism that involves a moderate (but effective) state intervention" (Bresser-Pereira, 2018). Thus, developmentalism is still a primary system that is imminent in Indonesia's economy.

Developmentalism paints that prosperity was created by the imperfect dynamics of competition and industry's lease, divided into the capitalist (higher profit), employees (higher labor), and state (higher tax). The basis of developmental states is on its ideology, legitimacy, and on its ability to get out of the poverty trap that has been longing for time; able to grow up promoting sustainable economic development. The capability to increase the economic conditions of its citizens is both the target of the edict elite's intention to keep the state's power.

With the socalled "enlightened despotism" from 1700s Europe to the East Asian developmental states after World War II, this matches as the result of the causes. In order to achieve the goals, a strong; loyal, decently pinpointed bureaucracy with its national interest needs to be included in the state's willingness. Developmentalism often tangled a hardship in the agricultural fields in order to finance industrialization, many cases founded around Asia, Russia, and Latin America.

The base of the developmental states market commonly depending on private capital and ownerships with the capability to stimulate, shape, and cooperate with one another. The interest of the industrial project goes along with the economic goals of the state. It will be a common value between the private sectors, affecting the technological capacity of the nation that is often dominated by companies based in wealthier countries. This also works the same way with the communist. From the explanations above, it can be said that the developmental state is the transition phase between poverty, industrialization to a powerful national economy.

Nevertheless, in the globalization age, the horizon of information and technology has also been reached among countries, thus the developmental state's planning based policies become increasingly obsolete and inefficient (Kattel et al., 2010). Thus, if once a country achieves technological advancement, everything will be developed enough until peak efficiency is present that eliminates unnecessary bureaucracy and policies. Moreover, if the manufacturing sector grows larger, it needs bigger markets as well and would be involved in freer trade with the rest of the world. So a successful developmental state carries the seeds of its own destruction for more than one reason since the bureaucratic and political dilemma of advancing step by step or one particular sector such as technology, then engaging other sectors to be advanced. Therefore, if developmentalism is only a process of progress toward the desired economic target, then why do most Asian countries keep developmentalism intact, Indonesia and Korea for instance. Indonesia and Korea are interestingly fascinating since both countries are middle power countries (Karim, 2018) with developmentalism on their hands (PARK, 2016). Therefore, in this paper, we try to explain how developmentalism in Indonesia is still relevant through comparison with Korea's developmental process under a similar path of the economy that "the state in Korea and Indonesia played a crucial role in economic development. It reflected on the choice of strategy and development plan, the role of technocrats, and the relationship between government and big businesses" (Winanti, 2002).

To find the novelty of this article, previously, the authors conducted some literature reviews to find a gap in this developmentalism issue. Indonesia and Korea as a comparison 
in terms of political economy is an interesting part to look at the beginning of this developmentalism theme that surrounds this paper.

The concept of developmentalism has adjusted to the development of socio political dynamics at any time in many countries. For example, developmentalism is being carried out by Indonesia and South Korea today. Historically, for South Korea, the concept of developmentalism is still used because of the relational strategic approach by South Korea (Gyoon, 2011). The adaptation of South Korean developmentalism is evident when on a local and regional scale the South Korean power which has become the nature of South Korean developmentalism has become a highly politicized territorial interest, resulting in complex interactions over the spatial differences of the South Korean State, unequal regional growth and territorial political parties from the 1960s to the present. Thus, an understanding of South Korean neo developmentalism emerged which was oriented towards construction through every aspect of life. In addition, developmentalism has been a constituent ideology for the last thirty to forty years on the basis of South Korea's daily politics, society, economy, and culture (Cho, 2003). Moreover, developmentalism has grown and manifested in an atmosphere of state economic development, supported by strong leadership and repressive rules against the public during the capitalist industrialization method.

Developmentalism is also not always in the context of infrastructure development. In South Korea, the justification for the causes of social security that was initially adopted in Korea was not universalism, but developmentalism (Kim \& Kim, 2008). In this context, developmentalism shows an advantage in explaining changes in Korean social security. Moreover, social security, such as pension benefits, affects the prosperity and equality of South Korea. Therefore, developmentalism can be used as a basis for more minimal benefits for social security measures in South Korea.

No different from South Korea, Indonesia also presents strong leadership and repressive rules for the public in implementing its developmentalism. Article with the title "A Comparative Political Economy of Development of Korea and Indonesia: Historical Structuralists Explanation", a comparison between Indonesia and South Korea's political economy development and argues using a historical structural approach as the basis for analyzing the two countries. However, the results of the intervention in the two cases that occurred in the two countries showed different outputs and standards that could show the success of economic development in South Korea (Winanti, 2002).

The term developmentalism is used to describe the revival of East Asian nation's economies after the Second World War. For instance, East Asian nations (e.g., Japan, Taiwan, and South Korea) were notable for being the successful 'developmental' country during the economic recovery process of the Post Second World War. Within the aims to boost the industrialization process by establishing efficient bureaucracies and also implementing interventionist economic policies, East Asian nations managed to exercise their developmental systems efficiently (Warburton, 2016). Warburton also mentioned that the idea of 'developmentalism' was meant to describe the ideas and practices of the state to achieve rapid development and to catch up with advanced countries.

Unlike classic developmentalism, New Developmentalism offers the middle ground between economic liberalism and Soviet style statism. New Developmentalism proposed an alternative form of capitalism and added the touch of state intervention in the political economy policy. The combination of state intervention was packed with historical references, such as the failure of neoliberal systems in the world. New Developmentalism noted that there are two alternative forms of economic organization of capitalism (BresserPereira, 2020). Firstly, marketled economic systems and excluding the state from 
coordinating the economic flow (economic liberalism). Secondly, the one who views the market as a 'battleground' for economic competition but also accepting the moderate amount of state intervention in coordinating the non competitive industries, the financial system, and the prices that the market is unable to control (Bresser-Pereira, 2020).

\section{METHOD}

In this article, the author uses qualitative research methods. The qualitative research method describes a new finding that had never existed before. These findings can be in the form of a description or description of an object that was previously unclear so that after being examined it becomes clearer, which can be in the form of a causal or interactive relationship, hypothesis, or theory (Ahyar et al., 2020). The data collection technique used by researchers is library research or library research, by collecting theoretical data from various books and journals related to developmentalism in Indonesia and South Korea. By definition, library research is a study used in collecting information and data with the help of various materials in the library such as documents, books, magazines, historical stories, etc. (Mardalis, 1995). The data analysis technique used in this research is qualitative data analysis techniques. Qualitative data analysis techniques are applied by analyzing \& revealing problems from the data obtained then linking them to the theories and concepts used (Sugiyono, 2019).

\section{RESULT AND DISCUSSION}

Developmentalism is defined by avoidance of law change, corruption, and even good governance to politically sensitive issues (Warburton, 2016). Therefore, it offers conservative means, as it is characterized by a reluctance to take action on sensitive political issues, such as good governance, human rights issues, and also corruption. Institutionally, the new development administration wanted to catch up with economic growth by adjusting regulations. This characterization was seen in the Jokowi era because President Jokowi had calculated that politically sensitive reforms would jeopardize his political stability. At this stage, the Jokowi administration seems to be avoiding anti corruption, human rights, and justice issues, as they are more interested in taking a progressive approach to economic and infrastructure development. Therefore, we can conclude that the new developmentalism is a policy focus that is pragmatic, statistnationalist oriented, and prioritizes political stability in order to support economic reform.

Although the new developmentalism is heavily influenced by economic forces. This is not only economic focused development but can transform into human development when the five ultimate goals (namely, security, individual freedom, economic development, social justice, and environmental protection) are met. The new principles of developmentalism trace back the history of Indonesia's presidency, new developments by President Joko Widodo are thought to echo the famous 'New Order' agenda in the past. The 'New Order' era, led by President Soeharto, was a centralized government, inward focused policies, a technocratic agenda, and its conservative nationalist features.

Despite Jokowi will lead Indonesia until 2024 or his second term. This paper will focus on the first term of his presidency. In the president's view, these structural problems are subordinate to the more urgent goal of rapid economic growth. As President Jokowi stated in his speech at the commemoration of the 55th Anniversary of Bhakti Adhyaksa, that economic development is the main "commander", if there are several obstacles that occur it must be removed, including law enforcement and the eradication of corruption which often destabilizes the Indonesian economy (Marta, 2016). This study then decides to 
compare Jokowi's developmentalism with the South Korean process of developmentalism under President Moon Jae-In in order to give a glimpse of how developmentalism still relevant in Indonesia. As mentioned before, Indonesia and South Korea have similarities in managing a capitalist economy with national interest through government play.

The comparisons are meant to give perspectives that Indonesia is still managing government and economy through developmentalism way like the New Order. Therefore developmentalism is still relevant in Indonesia. Like Indonesia, South Korea as a compare son also will be explained that Moon Jae-In's presidency also not very much different from Kim Dae-Jung's term, thus Indonesia and Korea are still under similar developmentalism schematic for their governance even in the globalization era.

In this section, this study will explore how Joko Widodo's presidency is not so different from Indonesia's previous government, which emphasizes developmentalism. Then this study will compare it to explain the South Korean case under President Moon JaeIn. Why President Moon Jae-In, because he is in time while Joko Widodo takes his oath in Indonesia while both of them relive past government policies for their policies. Finally, in the latter part of this section, this study will reflect on how developmentalism thrives in the globalization era to brief the two part analysis of this section.

\section{Joko Widodo's Case}

During the administration of President Joko Widodo (Jokowi) for one and going to two periods, Indonesia has experienced various advanced infrastructure development. At his first term in 2014, economic growth and infrastructure development for both land and sea were his top priority over the next five years. During his first term, his presidency was defined by a stateled development and focused on catching up with the country's lagged infrastructure through a policy referred to as "Jokowinomics". Jokowinomics embodied in the form of investment also funding injections into a stateowned company aimed at accelerating infrastructure development while increasing industrial capacity with the aim of increasing Indonesia's competitiveness. Although this Jokowinomics development model does not provide a new breakthrough even with President Soeharto's development style, this model is also highly characterized by President Jokowi's leadership character which is results oriented to quickly solve various problems (Sai'o, 2019). Jokowinomics also ramping up the distributions of Dana Desa or Village Fund, a program where local village heads receive grants to invest in local development (Guild \& Chen, 2019).

For instance, in Jakarta, there is the inauguration of Indonesia's first MRT (Mass Rapid Transportation) in 2019 and also the full renovation of Soekarno Hatta International Airport with the addition of a sky train between terminals. Beyond the capital, Trans Java Toll Road, Trans Kalimantan Highway, Trans Sumatra toll road, and Trans Papua highway are under completion. Until 2019, Jokowi's reign has completed 782 kilometers of new toll roads. By comparison, his predecessor President Susilo Bambang Yudhoyono has constructed 229 kilometers. All the projects are carried or cooperated by the state's arms.

Uncertainty in the global economy leaves a big impact on Indonesia's financial situation. Although Bank Indonesia managed to combat the rise of inflation and widening the current account deficit and safeguarding the country's financial fundamentals, there were several important reforms during Joko Widodo's first run. The most important is the elimination of fuel subsidies. The fuel subsidies were a major burden on the government's budget balance. This occurred because the Indonesian oil output has been declined over the past two decades and supported by the globe's low crude oil prices. Unlike his predecessors, President Susilo Bambang Yudhoyono failed 
to overcome the backlash of fuel subsidies elimination, through public outrage and mass demonstration (Schaar, 2016).

One of Jokowi's goals is to turn Indonesia into a one-stop-shop for foreign investment. In his first two years in the office, the Indonesian foreign direct investment (FDI) slowly grows by 4.5 percent. Though, the domestic investment in 2011-2015 shown the major slow down due to Indonesia's economic slowdown and high interest rate environment. Although Indonesia seems to face big obstacles, these challenges may start to change as the Indonesian economy is finally revived, supported by moderate inflation and the higher consumers' purchasing power (Schaar, 2016).

Meanwhile, besides the success stories from Jokowi's first reign, there are many deteriorating facts regarding the social and political issues. During Jokowi's administration, his work mostly focused on domestic economic development, this resulted in his lack of interest in politics and treated the socio politics issue as a second priority. Baker (2016) describes him as a developmental president who exhibits the short sighted and reactive nature of his decision making. This resulted in an illiberal or antidemocratic manner, narrow political sensitivities, and ad hoc decision making. In 2018, the evidence of Jokowi's administration authoritarian twist like ignoring Papua's human rights issues and bolding corruption eradication has moved to a status quo, shown in the government's consistent efforts to obtain narrow, partisan benefit from the political instrumentalization and the manipulation of civil society cleavages (Power, 2018). Therefore, a wind of Lutheranism and state drive in the economy are bold in the Jokowi's administration even though coated with pluralist democracy and liberal values as the government seems to have a lack of interest toward social and political issues like corruption eradication and human rights. Therefore, the plutocracy seems to bring a New Order style of governance.

\section{Moon Jae-In's Case}

In essence, Moon Jae-In's government has still 'use' the chaebol to achieve certain national objectives like his predecessors (Denyer, 2018), such as the achievement of the North Korean issue, international competitiveness, and economic interest. This analysis obscures the class and, essentially, the capitalist nature of the state. The point is that not only was the chaebol is the 'agents of the state's purpose' but that the primary objective of the state was to promote the development of the chaebol. From the start, the Korean development state has shown a commitment not just to 'growth' or 'development,' but to capitalist development. The policy of developing and supporting major state capitalist firms was at the core of the state's economic strategy. The fact that the state sought to control and dominate these firms does not change the fact that developing private investment was the reason for the existence of the developing state of Korea.

The government might have not chosen to act at the behest of the capitalist class (which is created) and it has committed itself through acting for its interests (Cumings, 1984). Intensive systems of government control have created a series of profound microeconomic distortions that cannot be seriously addressed without intentionally causing a major crisis. That being said, the choice to progressively open up the economy and relating Korean companies and financial firms to global market judgments without addressing these issues effectively made a crisis inevitable. The 1997-1998 crisis did play an extremely valuable hand in shaping a political and economic space for the state to resolve the serious problems of firm level financial structures. It therefore must be seen as an essential part of Korea's neoliberal reform 
process. The neoliberalism task should, in the switch, be more of a rational attempt by the Korean state to secure its position as a major center of accumulation in a changing global economy. Consequently, as is commonly claimed, the crisis cannot be understood as the product of a poorly implemented or simply a misguided liberalization initiative. Rather, it was an inevitable episode in Korea's historic economic rise.

In developing and national industrial countries, the focus of industrial policy was on developing specific 'national champions.' The objective of the policy was on the micro level. Major corporations have been selected and, in many cases, not only support for R\&D as well as other forms of subsidies and even a level of protection from international competition. Indeed, in several countries (such as Japan and Korea) that have undisputedly pursued highly active leading industrial policies in the post war era, public R\&D has traditionally been relatively unimportant (Murphy, 2002). There was a sense in the developing and national industrial countries that key firms had to be supported, not because they had great potential on the global marketplace, but simply because there was a sense that a 'great country' should have certain industries.

In the case of Korea, it is clear that the State has consistently applied two key principles to the promotion of restructuring. First, the government does seem to have a clear determination to push firms and financial institutions, no matter how strategically important they could be, to enhance their profitability or to leave the market. In other words, the state acted to complement and partially replace underdeveloped market discipline mechanisms by forcing firms to focus on the 'bottom line' and promoting creative destruction processes. At any given time, countries are under pressure to innovate their policies and power structures to maintain and improve their respective roles in a changing global economy. However, the extent to which global economic constraints affect individual states is critically dependent on the specific position they represent within the framework of global economic and political structures. Chaebol reform may be needed to give a better economic climate for South Korea, yet President Moon embraces Korean tycoons in order to support his policies such as Further South and North Korea. It is obvious that the gigantic companies of South Korea have been main allies in its appeal to North Korea (Denyer, 2018). Furthermore, for the New Southern Policy, South Korea brings Hyundai, POSCO, and Samsung ensemble to march on ASEAN's biggest economy, Indonesia, to secured South Korea's southeast Asian interest as argued by (Whiteside, 2017).

Furthermore, the fact that states must adapt to new rules of global competitiveness to compete effectively in the global economy somehow doesn't require giving them the capability to do so. Most countries outside the core capitalist system could not consistently respond to the challenges of global competitiveness. Hence, the intraelite connection becomes persistent even coated in the new mask in the globalization era (Vu, 2007).

\section{Reflection toward Indonesia and SK's Developmentalism in Globalisation Era}

Indonesia and South Korea share a similar economy, which is the role of government play in their capitalistic economy. Developmentalism seems to be a logical option in Asia as the developmental state model is still an effective development strategy in the post Cold War period and even in the era of globalization (Hayashi, 2010). This means, developmentalism still relevant as argued above, we have revisited a little nostalgia of how President Joko Widodo adapts the way the Indonesian New Order's response to some issues as guiding the economy by the hand of his government through projects and policies. In fact, not infrequently the decisions taken are quite fast 
and rely on investors to invest in Indonesia. While South Korea still vividly showing that government supports are vital even in an open and liberal economy like South Korea.

Moreover, the pragmatic position of the state is basically developmentalism as governments of emerging and newly developed countries integrate their economies economically into foreign markets, as well as aligning good governance proportionately (or even totally neglect it) in order to produce the required economic growth for the economies that are about to take off (Hayashi, 2010). This activity is very necessary where no country can avoid global trade activities for its national interest. Therefore, before integrating the national economy into the global economy, the state must first make adjustments so that it can maximize the fulfillment of national development.

Furthermore, the globalization era signed with open and free economy relations around the globe. Therefore, With the knowledge, we know that liberal economic values endorsed open and broad sense of competition in the market, developing economies need a guarantee to prepare their readiness toward an open economy. Hence revisited previous policies, such as using private sectors with or for state interest, are one way to bring the good even the good may relative nowadays.

\section{CONCLUSION}

It is true that Joko Widodo comes from a very nationalistic (and socialistic to some extent) party, yet we also know that he followed some steps that the New Order has made even though the New Order opposed his party. Strong government involvement to reach economic growth may become an old song that played back recently. Similar to Indonesia, South Korea revisited the old ways to face new problems in the new era. Despite the noise, the developmentalism way appeared to be potent and progressing in Indonesia's Joko Widodo the first term, and even in South Korea under Moon Jae-In today with their own distinction and style.

Developmentalism becomes limelight in almost every Asian politics. Strong government involvement toward desired economic or national interest with alignment to open economy as to grab growth become usual view in the Asia Pacific. Especially these two countries. Indonesia and South Korea now may resemble little Soeharto and little Kim Dae-Jung. Joko Widodo embodied the New Ordersh work mostly focused on domestic economic development, this resulted in his lack of interest in pursuing more forward democracy in Indonesia, such as corruption eradication and human rights. While Moon JaeIn embrace tycoons as Kim Dae Jung used corporatist channels for national interests. The intraelite connection still becoming a foundation in governance to bring policies that aiming national interest, politically and economically in these two countries like this study mentioned before.

\section{REFERENCES}

Ahyar, H., Auliya, N. H., Andriani, H., Fardani, R. A., Ustiawaty, J., Utami, E. F., Sukmana, D. J., \& Istiqomah, R. R. (2020). Metode Penelitian Kualitatif \& Kuantitatif (H. Abadi (ed.); 1st ed.). Pustaka Ilmu.

Baker, J. (2016). The middle class president. New Mandala. https://www.newmandala.org/comfortable-uncomfortable-accommodations/

Bresser-Pereira, L. C. (2018). Economic Nationalism and Developmentalism. Fiscaoeconomia, 2(1), 1-27. https://doi.org/10.25295/fsecon.2018.s1.001

Bresser-Pereira, L. C. (2020). A New Theoretical Framework: New Developmentalism. Challenge, 63(3), 114-132. https://doi.org/10.1080/05775132.2019.1705006 
Cho, M. K. (2003). The history and current address of Korean developmentalism. Environment and Life, 37, 31-53.

Cumings, B. (1984). The origins and development of the Northeast Asian political economy: industrial sectors, product cycles, and political consequences. International Organization, 38(1), 1-40. https://doi.org/10.1017/S0020818300004264

Denyer, S. (2018). South Korea's president once decried powerful tycoons. Now he needs them to woo Pyongyang. The Washington Post. https://www.washingtonpost.com/world/asia_pacific/south-koreas-presidentonce-decried-powerful-tycoons-now-he-needs-them-to-woopyongyang/2018/12/08/dfff8020-eefb-11e8-9236-bb94154151d2_story.html

Guild, J., \& Chen, J. (2019). 'Jokowinomics': Has It Worked? Think-Asia. http://hdl.handle.net/11540/10911

Gyoon, P. B. (2011). Territorial Politics and the Rise of a Construction-oriented State in South Korea. Korean Social Sciences Review (KSSR), 1(1), 185-220. http://hdl.handle.net/10371/75201

Hayashi, S. (2010). The developmental state in the era of globalization: beyond the Northeast Asian model of political economy. The Pacific Review, 23(1), 45-69. https://doi.org/10.1080/09512740903398330

Indraini, A. (2020). Terapkan New Normal, Erick Thohir: Sepertiga Ekonomi di BUMN. DetikFinance.

https://finance.detik.com/berita-ekonomi-bisnis/d5032621/terapkan-new-normal-erick-thohir-sepertiga-ekonomi-di-bumn

Karim, M. F. (2018). Middle power, status-seeking and role conceptions: the cases of Indonesia and South Korea. Australian Journal of International Affairs, 72(4), 343363. https://doi.org/10.1080/10357718.2018.1443428

Kattel, R., Drechsler, W., \& Reinert, E. S. (2010). Developmentalism. In Working Papers in Technology Governance and Economic Dynamics (Vol. 34, pp. 1-12). http://hum.ttu.ee/wp/paper34.pdf

Kim, S. K., \& Kim, S.-W. (2008). Developmentalism in Korea: A Useful Tool for Explaining the Role of Social Security in the Reduction of Poverty and Inequality. Asian Social Work and Policy Review, 2(2), 91-110. https://doi.org/10.1111/j.17531411.2008.00013.x

Mardalis. (1995). Metode penelitian: suatu pendekatan proposal. Bumi Aksara.

Marta, M. F. (2016). Empat Gebrakan Pemerintahan Jokowi Mendorong Ekonomi dengan "Menggadaikan" Hukum.

Kompas.Com. https://money.kompas.com/read/2016/05/03/071900926/Empat.Gebrakan.Peme rintahan.Jokowi.Mendorong.Ekonomi.dengan.Menggadaikan.Hukum?page=all

Murphy, M. (2002). The OECD small and medium enterprise outlook.

PARK, M. S. (2016). South Korea Cultural History Between 1960S and 2012. International Journal of Korean Humanities and Social Sciences, 1, 71-118. https://doi.org/10.14746/kr.2015.01.05

Power, T. P. (2018). Jokowi's Authoritarian Turn and Indonesia's Democratic Decline. Bulletin of Indonesian Economic Studies, 54(3), 307-338. https://doi.org/10.1080/00074918.2018.1549918

Sai'o, R. (2019). Jokowinomics and the Future Path for Indonesia's Economy. The Diplomat. https://thediplomat.com/2019/01/jokowinomics-and-future-path-for-indonesiaseconomy/

Schaar, R. M. . van der. (2016). Analysis Performance \& Accomplishments Indonesia Under Jokowi. Indonesia Investments. https://www.indonesiainvestments.com/news/news-columns/analysis-performance-accomplishments- 
indonesia-under-jokowi/item7286

Sugiyono. (2019). Metode Penelitian Kuantitatif Kualitatif dan R\&D. Alfabeta.

$\mathrm{Vu}, \mathrm{T}$. (2007). State formation and the origins of developmental states in south korea and indonesia. Studies in Comparative International Development, 41, 27-56. https://doi.org/10.1007/BF02800470

Warburton, E. (2016). Jokowi and the New Developmentalism. Bulletin of Indonesian Economic Studies, $52(3)$, 297-320. https://doi.org/10.1080/00074918.2016.1249262

Whiteside, D. (2017). South Korea's Moon unveils new focus on Southeast Asia. Reuters. https://www.reuters.com/article/us-indonesia-southkorea-idUSKBN1D900C

Winanti, P. S. (2002). A Comparative Political Economy of Development of Korea and Indonesia: Historicalstructuralists Explanation [International Relations and Political Economy]. https://core.ac.uk/download/pdf/213853078.pdf 